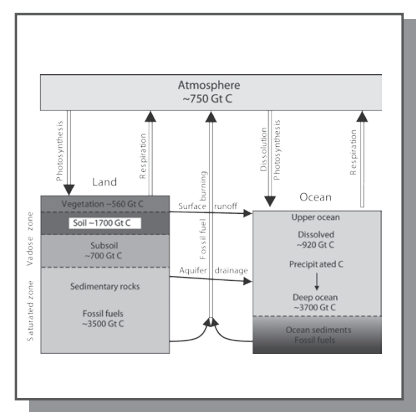

HANDBOOK OF CLIMATE CHANGE AND AGROECOSYSTEMS Impacts, Adaptation, and Mitigation 


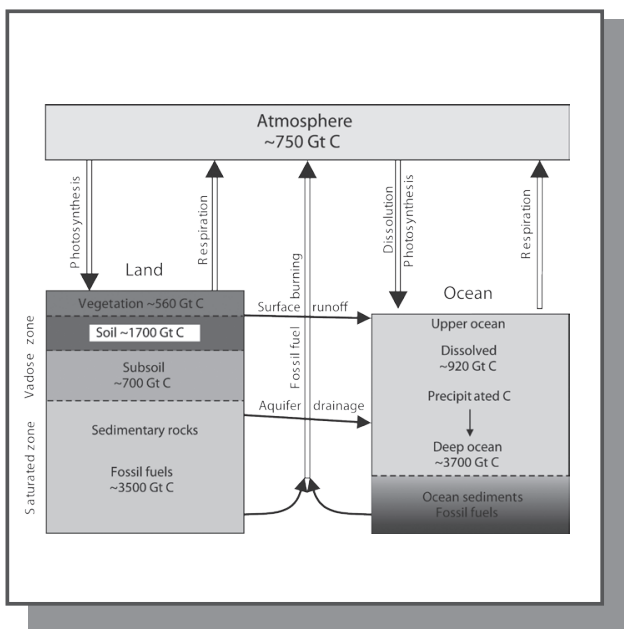

ICP Series on Climate Change Impacts, Adaptation, and Mitigation - Vol. 1

\section{HANDBOOK OF CLIMATE CHANGE AND AGROECOSYSTEMS} Impacts, Adaptation, and Mitigation

editors

Daniel Hillel

Cynthia Rosenzweig

Columbia University and Goddard Institute for Space Studies, USA 


\section{Published by \\ Imperial College Press \\ 57 Shelton Street \\ Covent Garden \\ London WC2H 9HE}

Distributed by

World Scientific Publishing Co. Pte. Ltd.

5 Toh Tuck Link, Singapore 596224

USA office: 27 Warren Street, Suite 401-402, Hackensack, NJ 07601

UK office: 57 Shelton Street, Covent Garden, London WC2H 9HE

\section{British Library Cataloguing-in-Publication Data}

A catalogue record for this book is available from the British Library.

\section{ICP Series on Climate Change Impacts, Adaptation, and Mitigation - Vol. 1 HANDBOOK OF CLIMATE CHANGE AND AGROECOSYSTEMS Impacts, Adaptation, and Mitigation}

Copyright (C) 2011 by Imperial College Press

All rights reserved. This book, or parts thereof, may not be reproduced in any form or by any means, electronic or mechanical, including photocopying, recording or any information storage and retrieval system now known or to be invented, without written permission from the Publisher.

For photocopying of material in this volume, please pay a copying fee through the Copyright Clearance Center, Inc., 222 Rosewood Drive, Danvers, MA 01923, USA. In this case permission to photocopy is not required from the publisher.

ISBN-13 978-1-84816-655-4

ISBN-10 1-84816-655-9

Typeset by Stallion Press

Email: enquiries@stallionpress.com

Printed in Singapore. 
ICP Series on Climate Change Impacts, Adaptation, and Mitigation

Editors-in-Chief: Daniel Hillel and Cynthia Rosenzweig

(Columbia Univ. and Goddard Institute for Space Studies, USA)

Vol. 1: Handbook of Climate Change and Agroecosystems:

Impacts, Adaptation, and Mitigation

edited by Daniel Hillel and Cynthia Rosenzweig 


\section{Preface}

The ICP Series on Climate Change Impacts, Adaptation, and Mitigation is dedicated to elucidating the integrated impacts of climate change, and to furthering effective responses to this global challenge. The series is designed to present and integrate the work of leading researchers in the world regarding climate change mitigation and adaptation for key sectors and systems.

The portending and all-pervading process of climate change, induced by the progressive anthropogenic accumulation of radiatively active gases in the atmosphere, can be expected to involve an exceedingly complex set of secondary effects and interactions. Because of their scale and complexity, the effects are likely to cascade through the entire biosphere and hydrosphere, impacting all life on earth and specifically bearing upon every aspect of human concern and endeavor.

Hence the task of anticipating the potential effects of climate change demands that scientists, who habitually concentrate upon specific sets of phenomena, deliberately widen their field of vision and cooperate across disciplines to encompass increasingly complex interactions. That trans-disciplinary cooperation, furthermore, entails developing effective responses to the changing climate. Such responses will include mitigation actions aimed at reducing the concentrations of greenhouse gases in the atmosphere (thus avoiding potential long-term risks) and adaptation strategies designed to accommodate and adjust to climate changes that cannot be avoided.

As the collective scientific and practical knowledge of the processes and responses involved in climate change continues to grow, the ICP Series on Climate Change Impacts, Adaptation, and Mitigation will address important aspects of the topic periodically over the coming years. Hence this volume is offered as the first in what is to be a continuing series on the interactions of climate change with a broad range of sectors and systems.

Daniel Hillel and Cynthia Rosenzweig

Editors 
This page is intentionally left blank 


\section{Acknowledgments}

The editors of this handbook acknowledge with gratitude the vital assistance of the following colleagues:

Dr. Dennis Timlin, the 2009 Program Chairperson of the American Society of Agronomy's A3 Division, which sponsored the symposium that has culminated in this publication;

Messrs. Joseph Gilbride and José Mendoza and Ms. Casey Jung of the Goddard Institute for Space Studies, Columbia University, who provided dedicated assistance in the detailed preparation of the manuscripts, illustrations, and index.

Dr. Zvi Ruder, the Senior Executive Editor on behalf of Imperial College Press, who initiated the series on Climate Change Impacts, Adaptation, and Mitigation; and Mr. Gregory Lee, the Production Editor, who so patiently and meticulously guided the publication process to its successful and timely completion. 


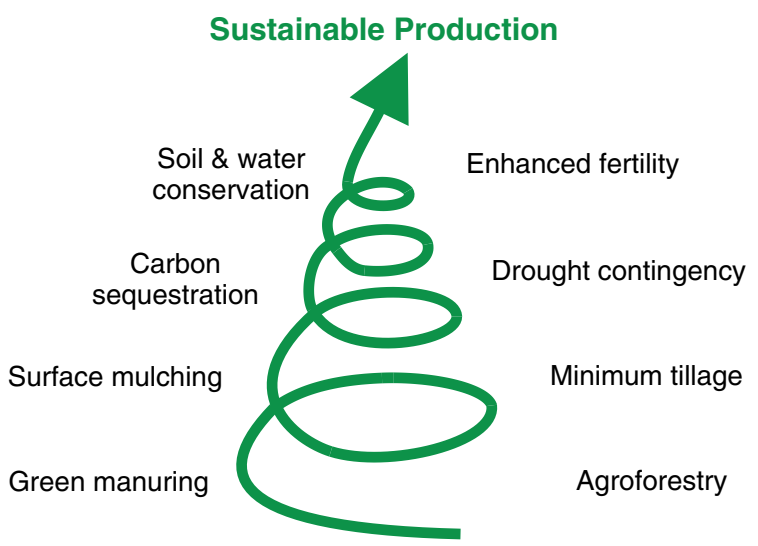

\section{Agro-ecosystem}

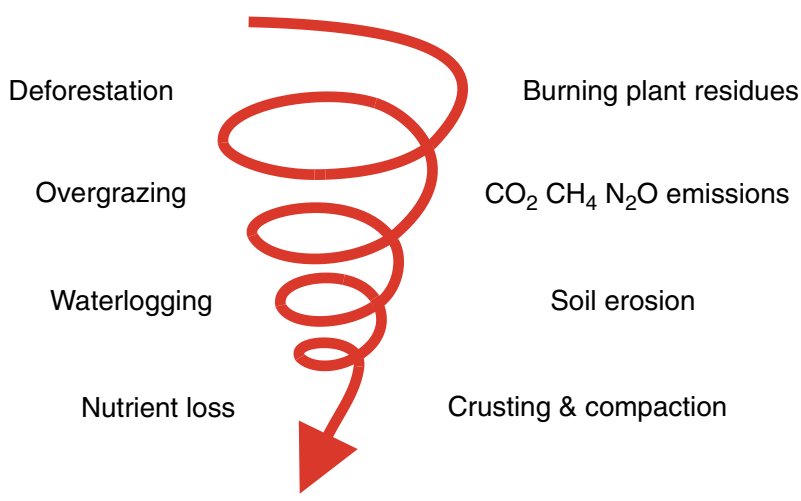

Degradation and Loss 


\section{Contents}

Preface $\quad$ V

Acknowledgments $\quad$ vii

Introduction Climate Change and Agroecosystems: Key Issues 1

Daniel Hillel and Cynthia Rosenzweig

\section{Section I. Broad-scale Interactions}

Chapter 1 The Role of Soils in Climate Change 9

Daniel Hillel and Cynthia Rosenzweig

Chapter 2 Fertilizing Change: Carbon-Nitrogen Interactions

and Carbon Storage in Land Ecosystems

Jerry M. Melillo, David W. Kicklighter, Hanqin Tian

and Sarah Butler

Chapter 3 Crop Yield Potential, Yield Trends, and Global Food

Security in a Changing Climate

Kenneth G. Cassman, Patricio Grassini and Justin van Wart

\section{Section II. Measuring and Modeling $\mathrm{CO}_{2}$ and Temperature Effects}

Chapter 4 Effects of $\mathrm{CO}_{2}$ and Temperature on Crops:

Lessons from SPAR Growth Chambers

David Fleisher, Dennis Timlin, K. Raja Reddy,

Vangimalla R. Reddy, Yang Yang and Soo-Hyung Kim 
Chapter 5 Lessons from FACE: $\mathrm{CO}_{2}$ Effects and Interactions

with Water, Nitrogen and Temperature

Bruce A. Kimball

Chapter 6 Testing Effects of Climate Change in Crop Models

Kenneth J. Boote, L. Hartwell Allen, Jr., P.V. Vara Prasad and James W. Jones

Chapter 7 Use of Crop Models for Climate-Agricultural Decisions

James W. Jones, Wendy-Lin Bartels, Clyde Fraisse,

Kenneth J. Boote, Keith T. Ingram

and Gerrit Hoogenboom

\section{Section III. Climate, Pests, and Regions}

Chapter 8 Climate Models for Agricultural Impacts:

Scales and Scenarios

Linda O. Mearns

Chapter 9 Precipitation: The Thousand-Pound Gorilla in Crop

Response to Climate Change

Thomas R. Sinclair

Chapter 10 Global Climate Change and Carbon Dioxide:

Assessing Weed Biology and Management

Lewis H. Ziska

Chapter 11 Climate Change Effects on Plant-Pest-Natural

Enemy Interactions

Andrew Paul Gutierrez, Luigi Ponti and Gianni Gilioli

Chapter 12 Climate Impacts on Agriculture in the United States:

The Value of Past Observations

Jerry L. Hatfield 
Chapter 13 African Agriculture in 2050: Climate Change Impacts and Adaptation Options

David B. Lobell

\section{Section IV. Adaptation and Mitigation}

Chapter 14 Guidelines for Adapting Agriculture to Climate Change

William E. Easterling

Chapter 15 Soil Carbon and Climate Change

Rattan Lal

Chapter 16 Quantification and Decision Support Tools

for US Agricultural Soil Carbon Sequestration

Keith Paustian, Stephen M. Ogle and Richard T. Conant

Chapter 17 Role of Biochar in Mitigation of Climate Change

Johannes Lehmann, James E. Amonette and Kelli Roberts

Chapter 18 Trade-offs Associated with Using Soil Carbon

Sequestration as Climate Change Mitigation

Angela Y.Y. Kong, Roberta Gentile, Pauline Chivenge, Steven J. Fonte and Johan Six

Chapter 19 Soil Carbon Sequestration for Mitigating Climate Change: Distinguishing the Genuine from the Imaginary

David S. Powlson, Andy P. Whitmore and Keith W.T. Goulding

Chapter 20 Economics of Agricultural Impacts, Adaptation, and Mitigation

John M. Reilly and Elodie Blanc 
Conclusion Climate Change and Agroecosystems: Main Findings and Future Research Directions

Daniel Hillel and Cynthia Rosenzweig

Index 